\title{
14
}

\section{Critical Assessment and Outlook}

\section{Carina Schmitt, Bastian Becker, Judith M. Ebeling, and Amanda Shriwise}

This volume has traced the role played by external actors in social protection in the Global South, from colonialism to international aid. The authors aimed at elucidating whether and how external actors and transnational relationships have influenced the formation, development and transformation of social protection arrangements. In this critical assessment and outlook, we first summarize the main findings of the book volume in a synthesized way (see section "Synthesized Summary"). Subsequently we discuss and critically evaluate our findings (see section "Discussion and Critical Evaluation"). A final section provides an outlook on potential future avenues for research (see section "Outlook").

C. Schmitt $(\bowtie) \bullet$ B. Becker $\bullet$ J. M. Ebeling • A. Shriwise SOCIUM Research Center on Inequality and Social Policy, University of Bremen, Bremen, Germany e-mail: carina.schmitt@uni-bremen.de; Bastian.becker@uni-bremen.de; judith.ebeling@uni-bremen.de; shriwise@uni-bremen.de 


\section{Synthesized Summary}

This book volume focuses on the role of external actors and transnational relationships from a more theoretical perspective in Parts I and IV, while Parts II and III present more empirically oriented chapters. The chapters of this book have contributed to studies on social protection in the Global South by ascertaining the types of external actors involved, how they exert their influence over time (see section "External Actors and Their Strategies from Colonialism to International Aid"), what their main objectives and preferences with regard to social protection look like (see section "External Actors' Objectives and Preferences Regarding Social Protection") and how they interact with domestic actors and in what ways their influence is conditioned, limited or translated by national factors (see section "Interaction with Domestic Factors").

\section{External Actors and Their Strategies from Colonialism to International Aid}

External actors have played a major role in policy-making from the very outset. Those contributions which focused on colonial times highlighted the role of European colonial actors, either comparing the British and the French colonial empires (Schmitt, Chap. 6, this volume; Becker, Chap. 7, this volume) or comparing cases within one of the empires (Mioni and Petersen, Chap. 3, this volume; Künzler, Chap. 4, this volume; Seekings, Chap. 5, this volume). Across empires, distinct imperial strategies led to differing approaches to social protection, despite the shared objective to decelerate the demise of the respective colonial empire (Becker, Chap. 7, this volume). Whereas the French focused on income maintenance of waged labor and the social insurance principle in their colonies (as reflected by the Code du Travail of 1952), the British Poor Law tradition led to an early diffusion of social assistance concepts (Schmitt, Chap. 6, this volume). Moreover, while the British typically used indirect rule, involving also non-state actors, the French employed more direct rule during colonial times. This is reflected by France's strong reliance on governmental actors for the distribution of aid to former colonies still today (Becker, Chap. 7, this volume). 
Strategies also differed within empires. For example, the British incorporated their territories into the colonial economy in different ways. Kenya's incorporation as a "labor reserve economy" and Tanganyika's as a "cash crop economy" led to higher taxation (and later more extensive taxfinanced social protection) in the former than in the latter (Künzler, Chap. 4 , this volume). Moreover, colonial actors were not homogeneous, such that colonial officials in the colony at times also acted in disagreement with those in the metropole for instance (Künzler, Chap. 4, this volume). In South Africa, the colonial-era design was retained despite the ruling elite's strong reservations about it, and as a result, the system of combining social assistance with 'semi-social insurance' was transferred from the preto the post-independence period. In addition to direct influence by colonial actors, Seekings (see Chap. 5, this volume) stressed the role of more indirect external influence through the diffusion of ideas. In the case of South Africa, these ideas came from Britain, Australia and New Zealand through white elites "embedded in imperial networks" (117).

International organizations started to become more significant external actors after the period of colonial rule. For instance, Mioni and Petersen (see Chap. 3, this volume) found that the International Labour Organization (ILO) played a more important role in social reforms in newly independent Burma than in colonial Malaysia. In both countries, it was the Cold War context-rather than the common British colonial heritage - that determined the timing of early social welfare reforms (Mioni and Petersen, Chap. 3, this volume). Other international organizations that became increasingly active in social protection in the Global South include multilateral agencies, like United Nations (UN) agencies (e.g. the World Food Programme in Botswana), or the international financial institutions of the World Bank and the International Monetary Fund (IMF) and bilateral ones, such as the UK's Department for International Development (DFID). Moreover, additional external actors like international non-governmental organizations (INGOs), advocacy networks and epistemic communities have become more and more involved. On the African continent, the four leading global agencies working in social protection today are United Nations International Children's Emergency Fund (UNICEF), DFID, ILO and the World Bank (Devereux and Kapingidza, Chap. 11, this volume). 
Often times, these international organizations employ a combination of financial leverage (i.e. providing or withholding aid) with technical support, expertise and policy recommendations (Dodlova, Chap. 8, this volume; Çemen and Yörük, Chap. 9, this volume; Devereux and Kapingidza, Chap. 11, this volume). Furthermore, strategies followed by contemporary external actors include, for example, setting norms and standards and building evidence (Devereux and Kapingidza, Chap. 11, this volume). However, the instruments at their disposal are at least at the surface those of "soft" rather than "hard" power, such that their influence may also be transmitted more indirectly and through ideational processes (Seekings, Chap. 5, this volume; Devereux and Kapingidza, Chap. 11, this volume; Haang'andu and Béland, Chap. 12, this volume; Barrientos, Chap. 13, this volume). Problematically, the policy ideas and norms disseminated by (contemporary) external actors are often presented as being neutral and universally applicable, despite being rooted in Western ideologies and likely to be shaped by Western political interests (Haang'andu and Béland, Chap. 12, this volume).

Moving from colonialism to international aid, certain changes and continuities among external actors involved in social protection-making can be observed. In Malaysia, for example, the British-run colonial government acted as a 'gatekeeper' against interference by international organizations in its territory, yet in newly independent Burma, not part of the British Commonwealth, the ILO was able to play a greater role. Here also national governments, other than those of the colonial metropole such as the US, began to play a part in social protection-making, in particular during the Cold War (Mioni and Petersen, Chap. 3, this volume). Nonetheless, the British maintained their post-independence influence through other channels, such as concentrating the work of their DFID in former British colonies (Seekings, Chap. 5, this volume). In fact, Becker was able to show that the colonial past affects the ways in which former colonial powers distribute aid still today, that is, to which sectors and through which actors international aid is distributed. Thus, aid is one way through which former colonial powers continue to exert their influence, particularly in the field of social protection (Becker, Chap. 7, this volume). 


\section{External Actors' Objectives and Preferences Regarding Social Protection}

There are various reasons for external actors to get involved in the field of social protection in countries of the Global South. They may be motivated by political objectives, like seeking to promote political stability as an antirevolutionary/anti-protest strategy. In Burma and Malaysia during the Cold War period, social reforms constituted part of anti-communism strategies. While the US, the UK and the ILO initially pursued differing agendasthe US being focused on its geo-strategic concerns; the UK on upholding the British Empire (later the Commonwealth); and the ILO on its more technical agenda — their interests eventually converged, ${ }^{1}$ allowing for high levels of coordination among them (Mioni and Petersen, Chap. 3, this volume). Containing social unrest was found to also be motivating social protection recommendations by the World Bank nowadays (Çemen and Yörük, Chap. 9, this volume). Haang'andu and Béland, but also Barrientos, stressed that the objectives of international organizations may in fact reflect the preferences of hegemonic countries that contribute to their resources (Chaps. 12 and 13, this volume). The ILO's activities in Burma and Malaysia, for instance, were also largely influenced by prevailing Western ideological concerns (Mioni and Petersen, Chap. 3, this volume).

However, international organizations may also differ with regard to their objectives. Künzler, for example, found that in both Kenya and Tanzania there was disagreement among the donor community on models for both pensions and health in the early 2000s. As a result, domestic politics appear to have played a more significant role, particularly in the case of the latter. In areas where there is less disagreement than in the field of education, donor influence tends to be greater (Künzler, Chap. 4, this volume). In Zimbabwe, on the other hand, inter-agency disagreements on how to best implement social protection turned the political arena into a "battlefield for external actors", namely the World Bank, UNICEF and the ILO (Devereux and Kapingidza, Chap. 11, this volume, 295). Part of the reason for this is that different international organizations may prefer dif-

\footnotetext{
${ }^{1}$ Not least due to the intertwined nature of communist uprisings and decolonization as well as the ILO's proximity to Western ideologies.
} 
ferent types of social protection. The World Bank, for instance, is the most prominent supporter of conditional cash transfers (CCTs), while UNICEF and DFID typically prefer unconditional family support schemes, and the ILO pursues a rights-based approach to social protection (Seekings, Chap. 5, this volume; Dodlova, Chap. 8, this volume; Devereux and Kapingidza, Chap. 11, this volume). Social pensions, on the other hand, are pushed to a lesser extent by external actors (Dodlova, Chap. 8, this volume). International organizations were also found to differ with respect to other program design questions. Whereas DFID and UNICEF are more likely to promote categorical targeting, the World Bank favors proxy means testing, among others (Dodlova, Chap. 8, this volume).

In the past, French colonial rulers supported family allowances to strengthen the core family, whereas social pensions are more likely to be found in (former) British colonies (Schmitt, Chap. 6, this volume). What is more, the early decision of the French to implement insurance-based social protection in its territories continues to decrease the likelihood of tax-financed, non-contributory social assistance being introduced in former French colonies today, as restructuring existing institutions would involve great costs. Conversely, the greater incidence of social assistance programs in former British colonies (in contrast to French ones) is linked to the Poor Law tradition guiding British colonial social policy (Schmitt, Chap. 6, this volume).

Despite external actors engaging in a broad range of social protection, including famine relief, pensions, health, disability policy and education, there has been an increasing focus on non-contributory social protection schemes, i.e. social assistance (or social cash transfers). This has significantly affected the balance between social assistance and social insurance in countries of the Global South (Barrientos, Chap. 13, this volume). Moreover, donor-financed social cash transfers have been criticized for their short-term focus as opposed to aiming for long-term social protection institutions - a dissonance that is also reflected by research on social protection in the Global South. Building sustainable, long-term institutions for social protection "requires deeper engagement with domestic politics" (Barrientos, Chap. 13, this volume, PAGE). Consequently, it is crucial to pay close attention to their interplay with domestic factors when examining the role of external actors. 


\section{Interaction with Domestic Factors}

On the one hand, there are instances in which the sway of the external actors supersedes that of domestic factors. In other instances, domestic factors considerably constrain and/or shape the scope of external influences. The legacy of French colonial rule, for instance, with its emphasis on the social insurance-based model appears to outweigh the positive influence of democratic institutions for the adoption of social assistance schemes (Schmitt, Chap. 6, this volume). In present times, external actors exert greater influence in countries that are dependent on aid and/or politically weak. The introduction of social protection reforms through external actors in Zimbabwe, for example, coincided with the country's economic collapse and significant domestic political uncertainty in the late 2000s (Devereux and Kapingidza, Chap. 11, this volume). Despite being largely independent of international aid, also Botswana was more susceptible to external support at key moments in its history, such as the drought in the 1960s or the AIDS crisis in the 1990s, when external actors were able to promote their agendas more efficaciously (Chinyoka and Ulriksen, Chap. 10, this volume). Similarly, UNICEF took advantage of the intensified political competition during the run-up to Kenya's national elections in 2002 to garner political support for its proposed child grant (Künzler, Chap. 4, this volume).

Moreover, social protection recommendations by the World Bank alone do not appear to have a strong direct effect on social protection spending in emerging economies. Yet, if preceded by certain cases of social unrest, general strikes in particular, policy recommendations by the World Bank are found to reinforce the positive relationship between social unrest and social protection spending (Çemen and Yörük, Chap. 9, this volume). In other words, domestic "social unrest plays a key role in how policy-makers translate structural forces into social policies and whether they choose to diffuse recommendations from IFIs" (PAGE). Furthermore, the influence of external actors appears to lessen when their agendas run contrary to domestic priorities. While having successfully lobbied for an unconditional cash transfer aimed at children in Kenya, external actors faced resistance from the Tanzanian government, whose 
affordability and long-term sustainability concerns led it to prefer productivist elements and conditions (Künzler, Chap. 4, this volume). In fact, in many sub-Saharan African countries indigenous concepts of informal social support and reciprocity do not combine easily with the emphasis on the individual inherent in the rights-based approaches of many Western external actors (Chinyoka and Ulriksen, Chap. 10, this volume; Devereux and Kapingidza, Chap. 11, this volume; Haang'andu and Béland, Chap. 12, this volume). The government of Botswana, for instance, has resisted the introduction of a poverty targeted cash grant, instead of emphasizing family/community, self-reliance and hard work (Chinyoka and Ulriksen, Chap. 10, this volume). Across the sub-Saharan region, the transnational disability movement has also failed to take into account context-specific norms and experiences of disability by falsely assuming the universality of Western paradigms (Haang'andu and Béland, Chap. 12, this volume).

Preceding the more recent wave of donor-supported social protection, the pre- and post-independence social protection models in Southern Africa were also not merely imposed by external actors but rather resulted from combinations of external ideas and predominant norms among local elites, adapted to local conditions (Seekings, Chap. 5, this volume). In the Cold War context in South East Asia, Western ideas on social reform were also adapted to local conditions, such as pronounced nationalism in independent Burma, and the quest for legitimatizing the state during transition from colonial rule to independence in Malaysia (Mioni and Petersen, Chap. 3, this volume). Accordingly, Burma's development plan in the 1950s was formulated in a way as to appeal to both foreign donors and potential nationalist critics. More generally, Haang'andu and Béland (Chap. 12, this volume) conclude that foreign external ideas can be adapted or translated to fit domestic conditions (ideational translation) or they can be combined with local norms to create new ones (ideational bricolage). The way in which external actors interact with domestic (f)actors has important implications for social policy-making and its longevity in the Global South. 


\section{Discussion and Critical Evaluation}

\section{Learning from Quantitative and Qualitative Approaches}

Following recent developments in the discipline, we approached the influence of external actors by way of quantitative and qualitative methods. Quantitative methods provide a bird's eye perspective, while qualitative methods delve into the intricacies of specific cases. Several well-known differences between the two methodological camps became also manifest in this volume. Where quantitative analyses often make strong assumptions about external actors and mechanisms, qualitative analyses shed light on how actors shape preferences and make specific choices. For example, Dodlova (Chap. 8, this volume) uses a quantitative approach that finds a correlation between specific social protection programs and the involvement of specific donors. However, on the basis of quantitative studies it is not possible to empirically assess whether this is a result of different donor preferences or whether recipient countries are strategic in the involvement of respective donors. As a consequence, the author points out that "it would be interesting to investigate this hypothesis on the basis of case studies and other qualitative research" (p. XX). Chapter 10 by Chinyoka and Ulriksen offers exactly such a qualitative study, attesting to the important role of domestic governments, especially their ideological stances. Similarly, Haang'andu and Béland (Chap. 12, this volume) argue that local demand for (external) social policy ideas is decisive for them to be implemented sustainably.

Similar comparisons, although with regard to colonial legacies, can be made regarding the quantitative chapters by Becker (Chap. 7, this volume) and Schmitt (Chap. 6, this volume), and the two qualitative chapters by Künzler (Chap. 4, this volume) and Seekings (Chap. 5, this volume). Both Becker and Schmitt sketch a broad picture, highlighting divergent preferences and institutions across colonial powers, in particular Britain and France. In contrast, the two qualitative chapters both compare social protection trends within the British Empire, each comparing two former colonies. This allows the authors not only to show how 
legacies of the British Empire become manifest in specific cases, but also to shed light on differences within the British empire, the importance of contextual factors and how these factors can condition colonial legacies.

While the attention to detail of qualitative studies facilitates the exploration of the agencies of different actors, quantitative studies more commonly aim at testing the generalizability of specific claims. As such, they capture average effects across a variety of geographic regions or determine statistical relationships over long timeframes. Case-specific insights such as those uncovered in the chapters by Chinyoka and Ulriksen (Chap. 10, this volume), Künzler (Chap. 4, this volume) or Seekings (Chap. 5, this volume) can inform quantitative studies that test their applicability more broadly. Whether such testing is possible depends much on data availability and on how easily concepts unveiled by qualitative research can be operationalized for quantitative measurement. The latter challenge is especially pronounced in relation to qualitative research in the constructivist tradition (e.g. Haang'andu and Béland, Chap. 12, this volume).

With regard to most aspects, the chapters within this book volume, even though applying different methodological approaches, succeed with speaking to each other. They sometimes reinforced each other's findings, at other times prompting further debate. While such debates often originate at the divide between quantitative and qualitative research, it is important to note that such debates can also be evidenced within each camp. For example, the qualitative studies by Künzler (Chap. 4, this volume) and Seekings (Chap. 5, this volume) attest to the importance of colonialism for the formation of social protection-making, but Mioni and Petersen (Chap. 3, this volume) find that this effect can be eclipsed by other factors, in particular Cold War politics. However, these debates are necessary to identify the national and international conditions for the influence of external actors on social protection pathways.

\section{Taking Scope and Context into Account}

In this book volume, the more quantitatively oriented chapters look at a broad set of countries, each covering the majority of the Global South. The qualitative chapters, with the exception of Mioni and Petersen 
(Chap. 3, this volume) who compare two South East Asian countries (Burma and Malaysia), zoom in on different African countries or regions. These qualitative chapters provide a close look at actors' motivations, strategies and relationships that cannot be achieved by macro-quantitative approaches. Even though most qualitative chapters have focused on African countries, some expectations regarding the transferability of insights from these African case studies can be formulated. On the one hand, bilateral donors and international organizations are involved in the design of social protection and a wide range of other policies, all across the Global South, even if to varying degrees. While the role of contextual factors should not be underestimated, the centralized character of these actors provides some reason to believe that corresponding insights from African case studies might apply more broadly. On the other hand, there are colonialism and Cold War dynamics and the long-term legacies of actors involved in both. While almost all countries in the Global South were affected by colonialism at some point, the intensity it reached in Africa was not as common in other world regions. This is especially true for Latin America, which the Portuguese and Spanish colonized well before the 'Scramble for Africa'.

Second, the influence of colonialism and Cold War on social protection in dependent territories and the succeeding nation states is far from being uniform. Quantitative chapters point out to broad differences between colonial empires, especially the British and French. Qualitative chapters emphasize complex interactions with pre-existing conditions and how external influence is translated into local ideas and action. At the same time, there can be other important influences, such as the Cold War, that drown out or moderate the effect of colonial dependencies. As such, even if colonialism and colonial legacies are a unique feature of social protection-making in the Global South, it necessitates further research into interrelationships with other influences.

Such interrelationships between external actors and domestic factors are not limited to the pre-independence period. On the one hand, many colonial effects are likely to carry on, as, for example, Becker (Chap. 7, this volume) has shown for international aid provided by former colonial powers. On the other hand, contemporary actors have their own goals and interests and similarly adjust their behavior to domestic conditions. 
The chapter by Çemen and Yörük (Chap. 9, this volume) on World Bank activities provides one such example. In addition to a new set of actors, there are other important differences between pre- and post-independence periods. For example, the sovereign control of external governments over territories in the Global South has largely vanished. Even though often these external governments still play a dominant role in countries that used to be under their control, they now have to compete for influence. How this new competition has altered these actor's responses to domestic conditions is an open question. While it goes beyond the scope of the present volume, research in this direction would provide further valuable insights.

\section{External Actors in the Global South and Global North}

This volume, with its focus on the role of external actors for social protection in the Global South, also aimed at counterbalancing comparative social policy research that is heavily tilted toward industrialized economies in the Global North. This leads to the question of whether social protection-making in the Global South underlies rules and processes which are fundamentally different from what we know from the Global North in the light of the findings in this book volume.

When summarizing the chapters of this book volume, we do confirm that social protection-making is different in some respects. Those chapters focusing on the long-lasting influence of colonial and Cold War superpowers show that for decades foreign governments tried to interfere in political, social and economic affairs of dependent territories or countries in the Global South. This included past but also contemporary social protection-making. At least colonial influence is not so heavily present in much of the Global North. Other chapters in this volume point out the importance of international organizations and donors in social protectionmaking in the Global South today. These actors provide ideational and financial resources to promote a variety of policies, including social protection. While some of these actors also influence policy-making in the Global North, they tend to be most involved and effective in the Global South. 
Moreover, most chapters in this volume have focused on external governmental and intergovernmental actors. While these actors play a central role on the international stage, be it historically within colonial empires or currently in the field of international development, they are not the only relevant ones. Research on welfare state development in the Global North emphasizes labor market questions and thus the role of firms. Economic actors such as companies should also play a decisive role in the Global South, where national governments compete for international investments and, more historically, where, for example, the large trading companies used to put strong demands on colonial governments.

Furthermore, it is worth reiterating and developing Barrientos' (Chap. 12 , this volume) earlier warning that external actors, especially international organizations, have strongly invested in advising and guiding policy-making and implementation. Therefore, they should also have an interest in research on their role in the Global South.

Additionally, there is the risk of researchers overemphasizing the role of external actors. Many international organizations provide data sources that greatly facilitate research but also focus on topics these organizations are interested in. ${ }^{2}$ As the impact of many external actors is considered to be global, or at least to affect a set of countries, it is also often easier for researchers to focus on the actions of external actors rather than to explore the actions of local actors who reside at multiple sites. As some chapters did in this volume, case studies - qualitative and quantitative-are a strategy that should be more frequently pursued. While they are timeconsuming, costly and data is less available, they are important for shedding more light on domestic processes and on how local actors adjusted to independence and work with external actors today.

While social protection-making in the Global South is different from that in rich democracies, it is important to be cautious about overstating its uniqueness. A search for similarities with the Global North might be also fruitful and provide explanatory power (Kpessa and Béland 2013). In this volume, an example of such work is the chapter by Çemen and

\footnotetext{
${ }^{2}$ At the same time other external actors, presumably fearing law suits or economic losses, might be eager not to provide any data for research purposes.
} 
Yörük (Chap. 9, this volume) who include countries from the Global South as well as the Global North in their analysis. Their findings suggest that the relationship between social unrest, World Bank involvement and social spending is comparably similar in both world regions.

\section{Outlook}

The chapters in this volume suggest several avenues for future research that may help to further specify changes and continuities with regard to the role of external actors in social protection arrangements in the Global South amid the shift from colonialism to international aid. This section discusses the future outlook in relation to transnational approaches to research design and methodology, geographic scope of research on social protection in the Global South, and transnational dynamics and actor constellations that shape, and are shaped by, social protection.

\section{Transnational Approaches to Research Design and Methodology}

From a conceptual standpoint, taking a transnational approach to research designs makes it possible to see how external actors and transnational relationships interact with domestic circumstances in ways that affect social protection arrangements in the Global South. From an analytical standpoint, while context is important to consider when analyzing social policymaking processes, greater emphasis needs to be placed on the identification of causal mechanisms, with attention to policy instruments, institutions and ideas in ways that are generalizable in order to contribute to theorybuilding. As illustrated by both Becker (Chap. 7, this volume) and Dodlova (Chap. 8, this volume), the presence of a policy instrument promoted or pushed by external actors such as development assistance/foreign aid provides a clear entry point through which to examine transnational processes affecting social protection in the Global South. Furthermore, the critical reflections by Haang'andu and Béland (Chap. 12, this volume) and Barrientos (Chap. 13, this volume) highlight the importance of viewing 
ideational and institutional mechanisms with a transnational lens first from the perspective of countries and peoples in the Global South, which draws attention to those aspects of social protection that are more deeply embedded rather than superficially imposed on countries.

Moreover, quantitative methods have distinct advantages in generalizability. However, generalizability is not only about sample size and average effects but also about the extent to which a finding in one context is applicable to another. The use of comparative methods of both the quantitative and qualitative varieties has the potential to make substantial theoretical contributions if thoughtfully designed. While it is important to keep pushing for higher quality comparable data on social protection systems throughout the Global South, strategically employing equivalencies in research designs also offers a way in which to extend the number of cases as well as a means of supporting pattern identification across different contexts in qualitative work. Together this could lead to theoretical advances in both quantitative and qualitative work that were previously unattainable.

Finally, this volume presents a clear call for more historical research in the social sciences. The findings by Schmitt (Chap. 6, this volume) suggest that colonial legacies play a key role in explaining differences in social protection arrangements in the Global South today, in ways that the shift to an international order has occluded. This is a critical methodological point. Transnational approaches to historical research help to ensure that external actors and transnational relationships influencing social protection arrangements during colonial times are not omitted from consideration, mistaken for being "new", or considered to be strictly domestic in nature. For instance, while the growth and role of non-governmental organizations have been increasingly recognized in recent literature on development and social protection, less attention has been paid to the way in which this growth is part of a broader shift away from religious missions and toward the secularization of third sector organizations, which began during colonialism and continued in the course of the twentieth century (Woodberry 2012; Dromi 2016). In sum, understanding how, in what ways and to what extent historical legacies affect current social protection arrangements requires an awareness of the ways in which transnational actors and relationships have impacted social protection arrangements over time. 


\section{Geographic Scope}

While many of the chapters have focused on Africa specifically, there is a need to expand understandings of the transition from colonialism to international aid to other regions, including Latin America, Asia and the Middle East. Moreover, international organizations but also colonial empires were often organized according to region. However, little is known about how regional geographies and organizations address crossborder challenges and affect social protection arrangements (Riggirozzi and Yeates 2015; Yeates 2014). For example, the foreign offices of colonial powers were often organized according to region, but also UN agencies are internally organized geographically. The effect of this on policy implementation remains largely unknown. Also, a growing number of regional organizations, ranging from the African Union to the League of Arab States to the South American Common Market, have all played a role in social policy-making throughout their member states. Additionally, there are countries and regions such as the Middle East or specific African and Asian states that are simply lesser examined in the literature, due to a lack of available data, language barriers, among other non-random factors.

Also, while this volume has focused predominantly on transnational relationships between the Global North and Global South, South-South cooperation and an increase in the number of middle-income countries (Surender and Urbina-Ferretjans 2015), transitioning from being recipients to donors, such as China, serves as a reminder that the future of transnational asymmetries may run from East to West as much as from North to South (Urbina-Ferretjans and Surender 2013). New lines of global conflict and contestation are likely to continue to shape the emergence of social protection; regional and sub-regional pockets of differentiation related to social protection, also referred to as "micro-paradigms" (von Gliszczynski and Leisering 2016), may emerge in line with current global trends and norms of social protection. 


\section{Transnational Dynamics and Actor Constellations}

This volume identified a shift in the transnational dynamics of social protection when moving from colonialism to the post-independence era. Current evidence suggests that the transformation of dependent territories into sovereign national states across the Global South might have empowered transnational actors. As territories throughout the Global South became sovereign nation states, former colonial powers were unable to utilize hard power instruments within these territories to achieve their aims. As a result, transnational actors, particularly intergovernmental organizations and international non-governmental organizations (Boli and Thomas 1997), were incentivized to exercise influence through soft power mechanisms.

Moreover, transnational actors such as intergovernmental organizations are not the only external actors that matter. As demonstrated particularly clearly in the case of Mioni and Petersen (Chap. 3, this volume), external influential national states might also behave transnationally. Superpowers such as the US and the former Soviet Union shaped the emergence of social protection arrangements in the Global South during the Cold War in line with their foreign policy interests and objectives. Considering how key states in the Global North view social protection within their foreign policy context may help to better understand the policy positions of international governmental organizations on social protection in the Global South. This is partly due to the fact that transnational actors appear to be of a dualistic nature. On the one hand, they are autonomous actors in their own right that may behave according to their own interests. On the other hand, they were largely created by, continue to receive financial support from, and may at times operate as instruments of powerful countries in the Global North. A better understanding of the interrelationships between influential nation states and international organizations, which also draw attention to the critical role of ideas and discourse in framing social protection in policy debates, would greatly enrich the state of the art.

Moreover, in line with Barrientos (Chap. 13, this volume), who emphasizes the importance of considering the drivers behind the emergence 
of domestic welfare institutions supporting social protection in the Global South, it may be important to re-examine the role of employers in the formation of social protection arrangements. From an historical standpoint, this requires considering the role and interests of concessional companies, as highlighted by Künzler (Chap. 4, this volume), in the formation of social protection arrangements during colonial times. The construction of labor markets and social protection in the Global South has clearly been impacted not only by colonialism but also by capitalism. While we know that social protection has been introduced in the Global South in a way that has been less clearly coordinated with domestic industrialization, we need to know more about the mechanisms through which employers exert influence on the structure of labor markets and social protection policies in the Global South as well as why, how and in what ways this legacy persists to date.

Considering transnational actor constellations and the ideas and institutions that influence their dynamics helps to address several gaps in the literature on social protection in the Global South by way of (1) specifying the linkages and asymmetries between external and domestic actors, factors and influences; (2) understanding how these relationships affect domestic policy-making environments in the Global South and (3) clarifying the mechanisms behind the introduction and reproduction of social protection arrangements. The emphasis placed on the need for transnational approaches (Shriwise, Chap. 2, this volume) should not be reduced to a focus on transnational actors alone (Barrientos, Chap. 13, this volume) nor should it exclude the examination of domestic/national actors and factors. The study of transnational actor constellations and their dynamics could help us to fill critical gaps in the literature. In so doing, we can gain a better understanding of the role of external actors for social protection-making in the Global South.

Finally, this work has critical implications for policy-making in the present. Careful research designs that are highly generalizable and the appropriate amalgamation and integration of findings across time and space can improve the quality of policy advice generated by academics, transnational actors and epistemic communities. For instance, the checklist generated by Devereux and Kapingidza (Chap. 11, this volume) serves as one example of a policy tool that can be iteratively refined in light of additional findings across a number of cases and contexts over time. 
Theoretically situating case studies is critical to ensure coherent and pluralistic theoretical development on the emergence of social protection in the Global South in ways that help policy-makers to move beyond the simple recognition that context matters. In so doing, it becomes possible to produce better guidance that supports evidence-informed policymaking and supports more sophisticated approaches to advancing human and social rights in complex policy-making environments.

\section{References}

Boli, John, and George M. Thomas. 1997. World Culture in the World Polity: A Century of International Non-Governmental Organization. American Sociological Review 62 (2): 171-190.

Dromi, Shai M. 2016. For Good and Country: Nationalism and the Diffusion of Humanitarianism in the Late Nineteenth Century. The Sociological Review Monographs 64 (2): 79-97.

Kpessa, Michael, and Daniel Béland. 2013. Mapping Social Policy Development in Sub-Saharan Africa. Policy Studies 34 (3): 326-341.

Riggirozzi, Pia, and Nicola Yeates. 2015. Locating Regional Health Policy: Institutions, Politics, and Practices. Global Social Policy 15 (3): 212-228.

Surender, Rebecca, and Marian Urbina-Ferretjans. 2015. 'New Kids on the Block?': The Implications of the BRICS Alliance for Global Social Governance. In Actors and Agency in Global Social Governance, ed. Alexandra Kaasch and Kerstin Martens, 130-152. Oxford: Oxford University Press.

Urbina-Ferretjans, Marian, and Rebecca Surender. 2013. Social Policy in the Context of New Global Actors: How Far Is China's Developmental Model in Africa Impacting Traditional Donors? Global Social Policy 13 (3): 261-279. von Gliszczynski, Moritz, and L. Leisering. 2016. Constructing New Global Models of Social Security: How International Organizations Defined the Field of Social Cash Transfers in the 2000s. Journal of Social Policy 45 (2): $325-343$.

Woodberry, Robert D. 2012. The Missionary Roots of Liberal Democracy. American Political Science Review 106 (2): 244-274.

Yeates, Nicola. 2014. The Socialization of Regionalism and the Regionalization of Social Policy: Contexts, Imperatives, and Challenges. In Transformations in Global and Regional Social Policies, ed. Alexandra Kaasch and Paul Stubbs, 17-43. Basingstoke: Palgrave Macmillan. 
Open Access This chapter is licensed under the terms of the Creative Commons Attribution 4.0 International License (http://creativecommons.org/licenses/ by/4.0/), which permits use, sharing, adaptation, distribution and reproduction in any medium or format, as long as you give appropriate credit to the original author(s) and the source, provide a link to the Creative Commons licence and indicate if changes were made.

The images or other third party material in this chapter are included in the chapter's Creative Commons licence, unless indicated otherwise in a credit line to the material. If material is not included in the chapter's Creative Commons licence and your intended use is not permitted by statutory regulation or exceeds the permitted use, you will need to obtain permission directly from the copyright holder. 